\title{
DETEKSI POSISI DALAM RUANGAN MENGGUNAKAN MIKROKONTROLLER ARDUINO DAN MULTI SENSOR
}

\author{
Henning Titi Ciptaningtyas ${ }^{1)}$, Royyana Muslim Ijtihadie ${ }^{2)}$, Wildhan Ibrahim Amin ${ }^{3)}$ \\ ${ }^{1}$ Jurusan Teknik Informatika, Fakultas Teknologi Informasi, \\ Institut Teknologi Sepulih Nopember (ITS), \\ Kampus ITS, Surabaya, 60111 \\ Telp : (031) 5939214, Fax : (031) 5939214 \\ E-mail: henning.its@ gmail.com ${ }^{1)}$
}

\begin{abstract}
Indoor Positioning System (IPS), a subsystem of locating object position system which the scope is inside the building, is a rapid growth research. Instead of using Global Positioning System (GPS), this system uses Wireless Fidelity (Wifi), Bluetooth, Infrared or other sensor for locating object. The problem with IPS using Wifi or Bluetooth is the object should be connected to the Wifi device or Bluetooth device. To overcome this, our system uses Ultrasonic sensor and Passive Infra Red (PIR) sensor to detect object position and those sensors are controlled by Arduino Microcontroller. We implement this system in hallway. The experimental result shows this system has good accuration rate to detect object inside the building.

\section{Abstrak}

Deteksi posisi dalam ruangan adalah bagian dari sistem pencarian posisi obyek yang ruang lingkupnya adalah di dalam ruangan atau gedung. Metode dan alat untuk deteksi posisi adalah riset yang terus berkembang. Jika deteksi posisi obyek di luar ruangan menggunakan GPS (Global Positioning System), maka untuk deteksi posisi obyek di dalam ruangan biasanya menggunakan CCTV, Wifi atau Bluetooth. Makalah ini dibuat untuk mengatasi kekurangan metode Wifi dan Bluetooth pada sistem deteksi posisi obyek yang mengharuskan obyek terhubung dengan alat. Penelitian ini juga mempunyai kontribusi yang besar pada sistem deteksi obyek dalam ruangan saat alat CCTV terhalang asap dan atau dalam kondisi gelap. Sistem yang dibangun ini menggunakan sensor ultrasonic dan sensor Passive Infra Red (PIR) yang dikontrol oleh mikrokontroller Arduino. Uji coba sistem ini dilakukan di lorong. Hasil uji coba menunjukkan sistem ini mempunyai tingkat akurasi yang cukup bagus dalam mendeteksi lokasi obyek dalam ruangan.
\end{abstract}

Kata kunci: deteksi obyek dalam ruangan, arduino, PIR, sensor ultrasonik.

\section{PENDAHULUAN}

Teknologi deteksi posisi obyek adalah pemetaan posisi seseorang atau benda lainnya dalam ruang lingkup tertentu. Jika di luar ruangan, kebanyakan menggunakan Global Positioning System (GPS). Jika di dalam ruangan, seperti sebuah gedung atau ruangan, media yang digunakan adalah CCTV, WiFi (Wireless Fidelity) dan Bluetooth. Tujuan deteksi obyek dalam ruangan antara lain sebagai alat bantu keamanan ataupun alat bantu pencarian korban jika terjadi bencana kebakaran atau gempa pada gedung.

Kekurangan dari penggunaan Bluetooth dan Wifi adalah sistem hanya dapat mendeteksi obyek yang membawa atau terhubung dengan kedua media tersebut. Jika tidak, maka obyek tersebut tidak akan terdeteksi. Sistem ini dapat digunakan sebagai alternatif ketika CCTV tidak dapat bekerja dengan optimal. seperti saat area tertutup asap (yang membuat jarak pandang semakin memendek) atau saat gelap.

Untuk mengatasinya, maka dikembangkan sebuah alat bantu untuk mendeteksi obyek dalam ruangan yang tidak menggunakan CCTV dan tidak harus terhubung dengan alat lain. Media yang digunakan sistem ini adalah sensor PIR dan sensor ultrasonik. Kedua sensor tersebut akan dihubungkan oleh Mikrokontroler Arduino. Perangkat tersebut diletakan di lorong gedung yang akan dipantau.

Adapun studi literatur yang digunakan dalam penelitian ini adalah sebagai berikut:

\subsection{Deteksi Posisi Dalam Ruangan}

Deteksi posisi dalam ruangan adalah metode untuk menemukan posisi obyek menggunakan satu atau lebih media, seperti gelombang radio, 
sinyal akustik ataupun informasi dari sensor (Kadir., A., 2013). Deteksi lokasi obyek dalam ruangan bisa disebut juga mini GPS (Global Positioning System), karena fungsinya yang mirip namun memiliki ruang lingkup yang lebih kecil. Pada penelitian ini, sistem deteksi lokasi obyek dalam ruangan dikembangkan dengan menggunakan sensor ultrasonik dan PIR sebagai pengumpul informasi pada lorong dan mikrokontroler Arduino Uno dan aplikasi berbasis Java sebagai pengolah data.

\subsection{Mikrokontroller Arduino}

Arduino (2014) adalah sebuah platform elektronik berbasis open source yang mudah digunakan untuk perangkat keras maupun perangkat lunak. Mikrokontroler Arduino tersedia dalam beberapa jenis, seperti: Arduino Uno, Arduino Leonardo, Arduino Mega.

Arduino Uno merupakan salah satu produk berlabel Arduino yang sebenarnya merupakan suatu papan elektronik yang mengandung mikrokontroler ATMega328 (sebuah keeping yang secara fungsional bertindak sebagai sebuah computer). Piranti ini dimanfaatkan untuk mewujudkan rangkaian elektronik sederhana hingga rangkaian yang kompleks (Arduino, 2014). Arduino Uno memiliki 14 digital input/output pin (dimana 6 pin dapat digunakan sebaga output PWM), 6 input analog, $16 \mathrm{MHz}$ ceramic resonator, koneksi USB, power jack, ICSP header dan tombol untuk reset (Curran, K., Lunney, F.T., Santos, D., Woods, D., Caughey, A.M., 2011). Pada penelitian ini, Arduino Uno digunakan untuk menerima dan memproses informasi dari sensor.

\subsection{Arduino Ethernet Shield}

Arduino Ethernet Shield berfungsi untuk menghubungkan rangkaian Arduino ke dalam jaringan internet dalam hitungan menit (Curran, K., dkk., 2011). Dengan menggunakan kabel RJ45 sebagai penghubung dan mengikuti sedikit instruksi sederhana, Arduino sudah dapat dikendalikan melalui jaringan internet. Hal ini karena adanya chip Ethernet Wiznet W5100 yang ditanamkan pada rangkaian tersebut. Selain itu Arduino Ethernet Shield juga didukung dengan slot MicroSD yang dapat digunakan untuk menyimpan berkas pengaturan jaringan.

\subsection{Sensor Ultrasonik}

Sensor ultrasonik adalah sensor yang memancarkan gelombang ultrasonik menggunakan transmitter dan diterima oleh receiver. Sensor ini bertujuan untuk menghitung jarak antara objek. Jarak diukur menggunakan rumus fisika yang ditunjukan oleh Persamaan (1), yang mana $\mathrm{S}$ adalah jarak (meter), $\mathrm{V}$ adalah kecepatan (meter/detik) dan $\mathrm{t}$ adalah waktu(detik). Karena sistem kerja dari sensor ini adalah menembakan gelombang dan menunggu pantulannya, maka waktu yang dibutuhkan harus dibagi dua (Harjion, P., 2014). Untuk kecepatan rambat gelombang di udara adalah $340 \mathrm{~m} /$ detik. Persamaan yang digunakan untuk menghitung jarak ditunjukan oleh Persamaan (2).

$S=V . t(1)$

Distance $=\frac{\frac{\text { time }}{2}}{29}=\frac{\text { time }}{58}(2)$

\subsection{Sensor Passive Infra Red}

Sensor PIR (Passive Infrared Receiver) adalah sensor pendeteksi gerakan dengan cara mengukur perubahan tingkatan inframerah (panas) yang dipacarkan benda sekitarnya (Parallax, 2014). Jika sensor PIR mendeteksi adanya gerakan, maka sensor tersebut mengeluarkan sinyal tinggi melalui pin output. Pada penelitian ini, sensor PIR digunakan untuk mendeteksi obyek.

\section{METODOLOGI}

Metodologi yang digunakan pada penelitian ini membangun sistem deteksi lokasi obyek dalam ruangan yang memanfaatkan sensor ultrasonik dan sensor PIR yang ditempatkan di lorong gedung. Kedua jenis sensor tersebut berfungsi sebagai penerima informasi tentang keadaan lorong yang kemudian diolah mikrokontroler Arduino Uno dan aplikasi desktop agar dapat menampilkan gambaran kondisi lorong.

Perangkat lunak pada sistem ini berbasis aplikasi desktop. Sedangkan untuk perangkat keras yang digunakan dibagi menjadi dua kelompok, yaitu:

- Kelompok pertama adalah beberapa sensor ultrasonik, sensor PIR, Ethernet Shield dan mikrokontroler Arduino yang ditempatkan pada lorong gedung.

- Kelompok kedua adalah desktop yang digunakan untuk menjalankan aplikasi yang diletakkan secara terpisah, namun tetap bisa saling terhubung dengan kelompok pertama menggunakan jaringan internet.

Untuk mempermudah pemetaan lorong dibagi menjadi area-area. Setiap perubahan status keberadaan obyek pada area tertentu akan dikirim ke sistem aplikasi desktop melalui jaringan komputer menggunakan Ethernet Shield dan kabel RJ45. 


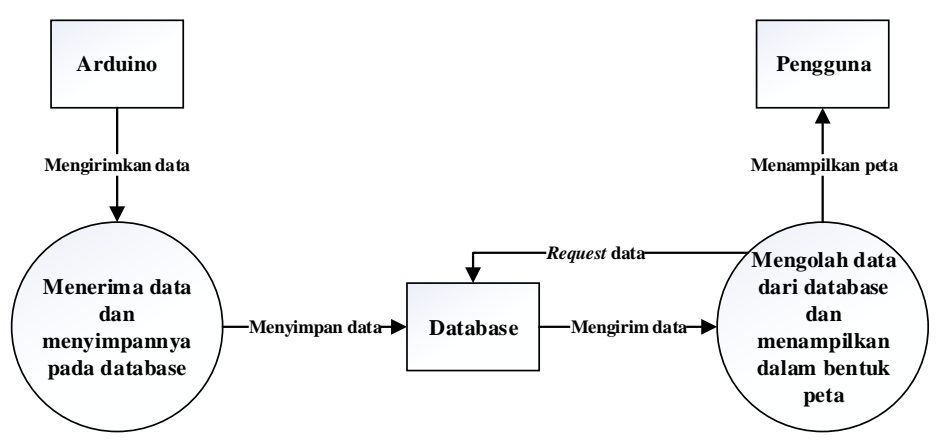

Gambar 3. Diagram Aliran Data

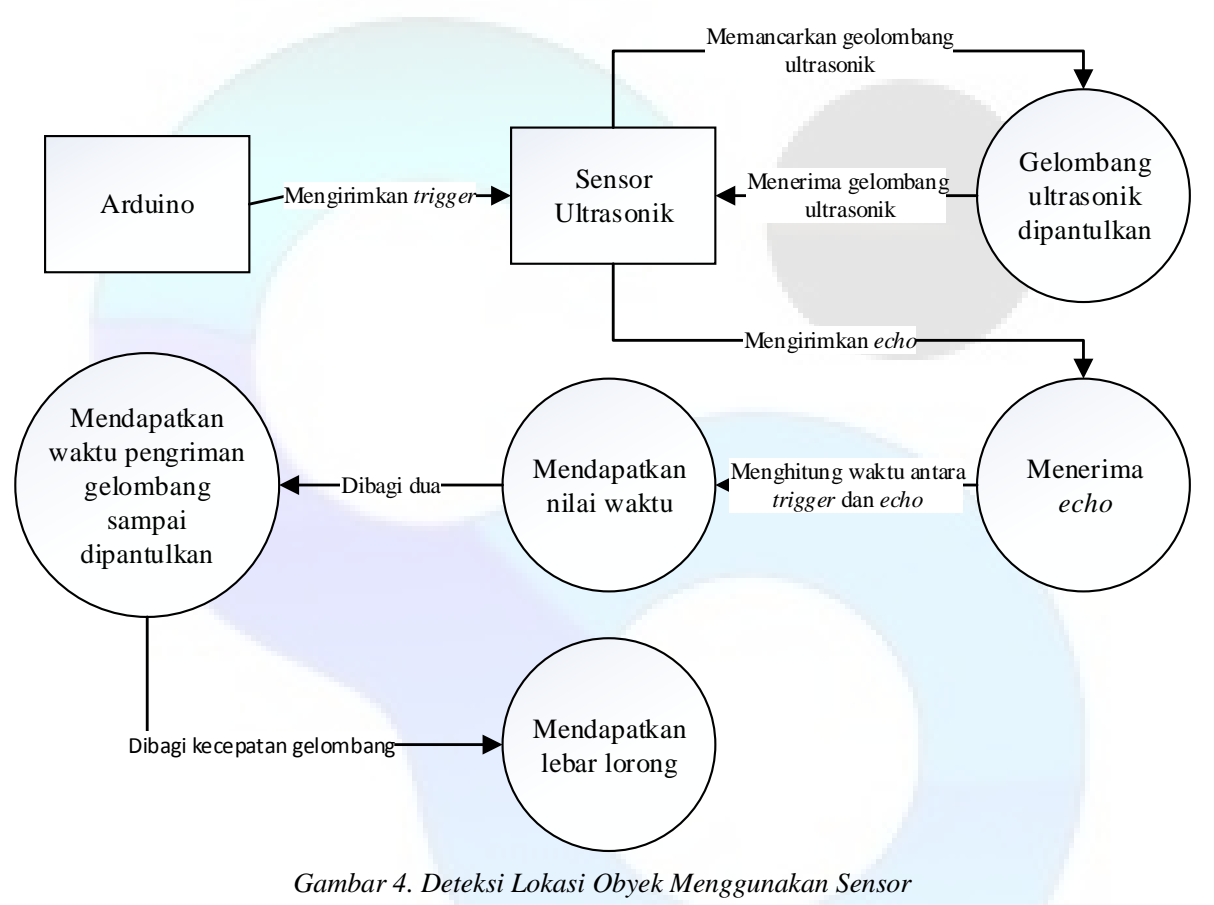

Pada desktop terdapat dua aplikasi yaitu IPS Server dan IPS client. IPS server berfungsi sebagai server bagi Arduino dan menerima semua informasi yang dikirimkan Arduino, lalu menyimpannya di database. IPS Client bertugas untuk menampilkan denah keadaan lorong dan berhubungan langsung dengan end-user.

Diagram aliran data bisa dilihat pada Gambar 3. Arduino menerima data dari sensor dan mengirimkannya ke database untuk disimpan. Saat pengguna ingin menampilkan keberadaan lokasi obyek dalam suatu ruangan, maka pengguna akan mengirimkan query ke database dan database mengirimkan ke pengguna untuk ditampilkan dalam bentuk grafis atau peta keberadaan obyek dalam ruangan tertutup.

Dalam melakukan proses deteksi obyek di suatu ruangan tertutup, alurnya bisa dilihat pada Gambar 4. Selama rentang waktu tertentu, arduino mengirimkan trigger ke sensor ultrasonic untuk memindai ruangan.

Kemudian sensor ultrasonik memancarkan gelombang ultrasonik melalui transmitter. Gelombang ultrasonik memantul saat mengenai tembok atau objek yang berada didepannya. Pantulan gelombang akan diterima oleh sensor ultrasonik menggunakan receiver dan mengirimkan echo ke Arduino.

Untuk mendapatkan nilai lebar lorong Arduino akan dihitung waktu yang dibutuhkan mulai dari Arduino mengirimkan trigger sampai menerima echo dan dibagi dua karena waktu yang dihitung hanya waktu yang digunakan gelombang untuk sampai pada dinding. Hasilnya akan dibagi dengan kecepatan gelombang ultrasonik yaitu $340 \mathrm{~m} / \mathrm{s}$ atau $29 \mathrm{~cm} /$ mikrosecond. Jika nilai lebar lorong sama dengan nilai acuan (saat keadaan kosong), maka tidak ada obyek di posisi tersebut. Sebaliknya, jika nilai lebar lorong lebih kecil daripada nilai acuan, maka ada obyek yang sedang berada di posisi yang dipindai oleh sensor ultrasonik tersebut.

\section{DESAIN SISTEM}


Desain sistem terbagi menjadi:

\subsection{Arsitektur Sistem}

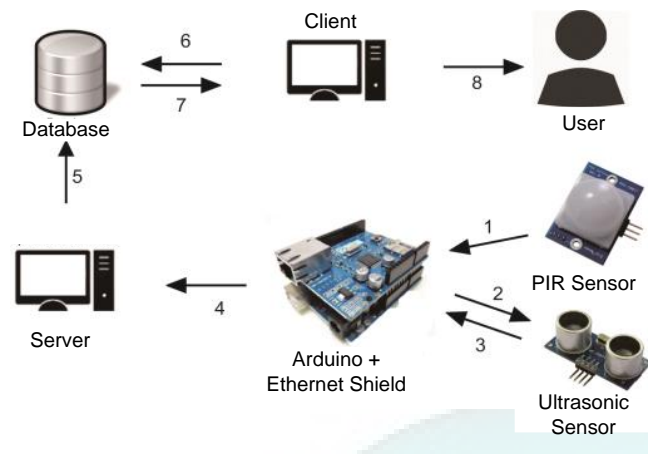

Gambar 3. Arsitektur Sistem

Arsitektur sistem bisa dilihat pada Gambar 1 dengan detil sebagai berikut:

1. Sensor PIR mengirimkan tanda ke Arduino bahwa ada objek yang memasuki area yang dijangkau oleh sensor.

2. Arduino mengirimkan trigger ke masingmasing sensor ultrasonik untuk menembakkan gelombang ultrasonik secara bergantian.

3. Arduino menerima tanda dari sensor ultrasonik bahwa gelombang yang dipantulkan telah kembali ke sensor. Arduino menghitung waktu yang dibutuhkan sensor untuk melakukan pantulan. Hasil perhitungan tersebut adalah nilai jarak.

4. Jika nilai jarak saat itu lebih kecil dari pada nilai lebar lorong, maka Arduino akan mengirim pesan ke Server bahwa ada objek di depan sensor ultrasonic.

5. Server membaca pesan tersebut dan melakukan pengubahan data status sensor di database sesuai dengan id sensor.

6. Client melakukan permintaan data status sensor secara berulang ke database.

7. Database mengirimkan data status sensor terbaru Client.

8. Client mengolah data dari database untuk ditampilkan kedalam bentuk denah sehingga mempermudah pangguna untuk membacanya.

Database berisi tabel Map dan tabel Sensor. Tabel Map berisi informasi mengenai peta, yaitu: nama peta, alamat penyimpanan peta, tinggi dan lebar peta. Tabel Sensor memuat informasi tentang posisi sensor ultrasonik pada denah yang mempunyai atribut id sensor, nama peta, koordinat $\mathrm{x}$, koordinat $\mathrm{y}$, lebar lorong sesuai ukuran denah, arah sensor, dan status sensor. ID sensor digunakan sebagai primary key. Format yang digunakan ID sensor adalah ip arduino + ":"(titik dua) + "U" + nomor sensor. Koordinat $\mathrm{x}$, koordinat $\mathrm{y}$, lebar lorong, dan arah sensor digunakan untuk menggambarkan area yang dicakup oleh sensor. Status sensor memuat informasi tentang area tersebut dalam posisi kosong atau tidak.

Aplikasi Client akan meminta data dari database secara berulang agar mendapatkan data yang mendekati realtime. Kemudian data akan dikirim oleh database ke Client. Data tersebut diolah dan ditampilkan pada denah lorong berdasarkan status areanya.

\subsection{Perangkat Keras}

Perangkat keras yang digunakan pada sistem dapat dilihat pada Gambar 2. Terdapat empat buah sensor ultrasonik dan sebuah sensor PIR yang dihubungkan ke mikrokontroller Arduino. Kabel berwarna merah berhubungan langsung dengan ground dan yang berwarna hitam berhubungan langsung dengan sumber daya (VCC). Kedua kabel dihubungkan secara paralel dengan semua sensor. Kabel yang lain dihubungkan secara terpisah ke pin masingmasing.

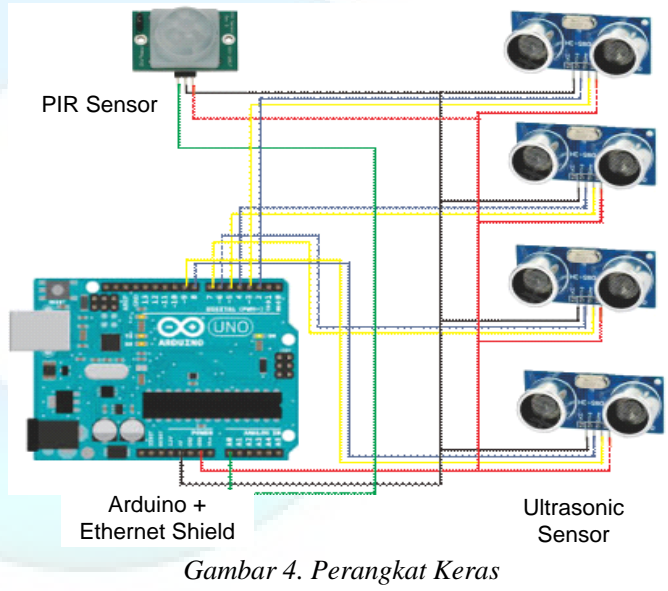

Sensor ultrasonik diletakan secara zigzag di kedua sisi tembok pada lorong. Jarak antara dua sensor ultrasonik di sisi tembok yang sama dihitung menggunakan persamaan (3). Sedangkan untuk sensor ultrasonik pada sisi yang berlawanan, diletakan di antara kedua sensor ultrasonik pada sisi yang sama.

$B C=2 \cdot\left(\right.$ Lebar $\cdot \tan \frac{1}{2} \angle$ SensorUltrasonik $)(3)$

\subsection{Aliran Data}

Sistem yang dibangun memberikan informasi area pada lorong yang ada obyeknya. Sistem diawali dari pengiriman data oleh Arduino ke server. Data yang diterima berupa status keberadaan obyek dari area lorong, lalu data tersebut disimpan di database. Aplikasi Client meminta data status area pada database. Data yang diterima kemudian diolah berdasarkan 
koordinat pada denah yang telah disiapkan. Aplikasi Client menampilkan denah lorong dan area dengan status "ada obyek".

\section{IMPLEMENTASI}

Implementasi perangkat keras diawali dengan menyusun rangkaian Arduino, kemudian menghubungkan Arduino Ethernet Shield dengan laptop menggunakan kabel RJ45. Setiap sensor ultrasonik dan sensor PIR diletakan di kedua sisi dinding dan saling berhadapan.

Untuk implementasi perangkat lunak, terdapat tiga aplikasi yang dijalankan pada dua perangkat keras, yaitu:

1. Aplikasi pada mikrokontroler Arduino yang mendeteksi keberadaan obyek pada lorong. Modul aplikasi ini adalah: modul penerimaan sinyal sensor PIR, modul pengukuran panjang menggunakan sensor ultrasonik dan modul pengiriman pesan dari Arduino ke server.

2. Aplikasi Server bertugas menerima pesan dari Arduino dan melakukan pemutakhiran data status sensor pada basis data. Aplikasi ini dijalankan pada laptop.

3. Aplikasi Client bertugas menampilkan area yang terindikasi adanya keberadaan obyek pada denah-denah yang telah disiapkan. Aplikasi ini dijalankan pada laptop.

\section{HASIL UJI COBA}

Pengujian dilakukan di lantai tiga pada gedung Teknik Informatika ITS. Posisi sensor pada gedung tersebut seperti yang ditunjukan oleh Gambar 5. Masing-masing rangkaian Arduino terletak di di depan ruangan IF-310 dan di sebelah kiri dari pintu ruangan IF-309.

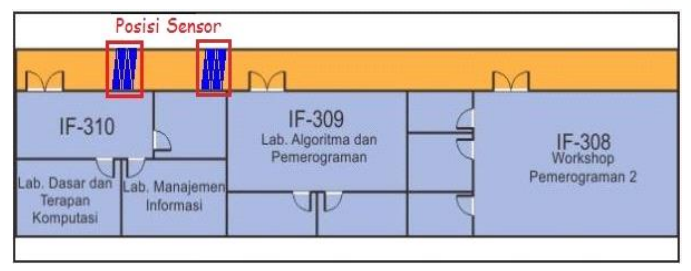

Gambar 5. Posisi Sensor

\subsection{Uji Fungsionalitas}

Pengujian fungsionalitas sistem dilakukan dengan menyiapkan sejumlah skenario sebagai tolok ukur keberhasilan. Pengujian ini dilakukan dengan menggunakan satu set rangkaian Arduino dan laptop. Fungsi yang diujikan adalah: deteksi posisi obyek oleh Arduino, pengiriman data dari Arduino ke Server dan menampilkan posisi pada aplikasi Client. Hasil pengujian dapat dilihat pada Tabel 1 .

\subsection{Uji Akurasi}

Pengujian akurasi sistem yang dimaksud disini adalah benar atau tidaknya sensor ultrasonik dalam menilai posisi dari obyek. Pengujian ini dilakukan dengan cara objek berdiri secara acak di area yang dijangkau oleh sensor PIR. Kemudian hasil keluaran dari sistem akan dicocokan dengan posisi obyek tersebut. Hasil keluaran dinyatakan sesuai jika sensor ultrasonik dapat menilai secara tepat kondisi dari area yang dicakup. Pada pengujian ini menggunakan dua set rangkaian Arduino.

Dalam pengujian ini disiapkan 22 macam skenario posisi objek. Pengujian ini dilakukan sebanyak dua kali dengan 15 skenario yang berbeda. Sehingga setiap skenario diuji minimal satu kali dan maksimal dua kali.

Hasil penghitungan presentasi ditunjukan oleh Tabel 2. Hasil rata-rata yang didapat total akurasi per total pengujian adalah $91.67 \%$.

Tabel 1. .Hasil uji fungsionalitas

\begin{tabular}{lll}
\hline ID & Nama Pengujian & Hasil \\
\hline UJ-01 & $\begin{array}{l}\text { Deteksi Posisi pada } \\
\text { Arduino }\end{array}$ & Berhasil \\
UJ-02 & $\begin{array}{l}\text { Pengiriman Data dari } \\
\text { Arduino Ke Server }\end{array}$ & Berhasil \\
UJ-03 & $\begin{array}{l}\text { Menampilkan posisi } \\
\text { obyek pada aplikasi } \\
\text { Client }\end{array}$ & Berhasil \\
\hline
\end{tabular}

Tabel 2. .Hasil uji akurasi

\begin{tabular}{lcr}
\hline Skenario & $\begin{array}{c}\text { Jumlah } \\
\text { Pengujian }\end{array}$ & $\begin{array}{r}\text { Presentase } \\
\text { Keberhasilan }\end{array}$ \\
\hline 1 & 2 & $93.75 \%$ \\
2 & 2 & $87.50 \%$ \\
3 & 2 & $81.25 \%$ \\
4 & 2 & $100.00 \%$ \\
5 & 1 & $87.50 \%$ \\
6 & 1 & $87.50 \%$ \\
7 & 1 & $87.50 \%$ \\
8 & 2 & $100.00 \%$ \\
9 & 2 & $93.75 \%$ \\
10 & 1 & $87.50 \%$ \\
11 & 1 & $100.00 \%$ \\
12 & 1 & $87.50 \%$ \\
13 & 1 & $87.50 \%$ \\
14 & 2 & $87.50 \%$ \\
15 & 1 & $87.50 \%$ \\
16 & 1 & $87.50 \%$ \\
17 & 1 & $100.00 \%$ \\
18 & 1 & $87.50 \%$ \\
19 & 1 & $87.50 \%$ \\
20 & 1 & $87.50 \%$ \\
21 & 1 & $100.00 \%$ \\
22 & 2 & $100.00 \%$ \\
\hline & Rata-rata & $91.67 \%$ \\
\hline
\end{tabular}




\section{SIMPULAN DAN SARAN}

Dari hasil selama proses perancangan, implementasi, serta pengujian dapat diambil kesimpulan sebagai berikut:

1. Sistem ini telah dapat menjalankan fungsinya yaitu mendeteksi keberadaan obyek manusia pada bagian lorong tertentu

2. Hasil rata-rata yang didapat total akurasi per skenario adalah $91.67 \%$.

Berikut saran-saran untuk pengembangan dan perbaikan sistem di masa yang akan datang. Diantaranya adalah sebagai berikut:

1. Menambahkan sensor-sensor yang dapat meningkatkan presentase dari keakuratan dari sistem ini.

2. Menambahkan fasilitas penyimpanan history atau log dari data yang dikirimkan oleh Arduino, sehingga data dapat dibaca di kemudian hari.

\section{DAFTAR RUJUKAN}

A. Kadir, 2013. Panduan Praktis Mempelajari Aplikasi Mikrokontroler dan Pemrogramannya Menggunakan Arduino. Yogyakarta: Penerbit Andi, 2013.

Arduino, 2014. Arduino Uno [Online]. Available at:

http://arduino.cc/en/Main/ArduinoBoardUno \#.UyiTCfl_u1U. [Accessed 5 Juli 2015].

Arduino, 2014. Arduino Ethernet Shield. [Online]. Available at: http://arduino.cc/en/Main/ArduinoEthernetS hield\#.UydAbPl_u1U. [Accessed 5 Juni 2014].

K. Curran, E. Furrey, T. Lunney, J. Santos, D. Woods and A. M. Caughey, 2011. An Evaluation of Indoor Location. Journal of Location Base, vol. 5.

P. Harjion, 2014. Anotherorion [Online] (Updated 13 June 2014) Available at: http://anotherorion.com/. [Accessed 15 Juni 2015].

Parallax Inc., 2014. PIR Sensor (Rev B) [Online]. Available at: http://www.parallax.com/product/55528027. [Accessed 15 Juni 2015]. 